Ayurlog: National Journal of Research in Ayurved Science

http://www.ayurlog.com Volume: $6^{\text {th }} \mid$ Issue: $5^{\text {th }} \mid$ August 2018

\title{
A comprehensive review of senile immature cataract and its correlation with kaphaj kach in ayurvedic literature.
}

\author{
Swapna R. Patil ${ }^{* 1}$, Shilpa Dhote ${ }^{2}$
}

1. P. G. Scholar,

2. Assistant Professor,

Dept. of Shalakya Tantra, College of Ayurved and Research Centre,

Nigdi, Pune, Maharashtra-18.

*Corresponding Author: Mob.: 9096943507, email : swapna07jadhav@ gmail.com

\begin{abstract}
:
Ayurveda, The science of life, since its origin is serving the mankind throughout in health \& disease state of life. Shalakyatantra, one of its specialized branch deals with the science Ophthalmology, Otorhinolaryngology, Orodental surgery \& Head; was contributed and developed by Rajrishi Nimi, the King of Videha, who was a colleague of Atreya, Punarvasu, Dhanwantri, Bharadwaja, Kashyapa etc. The available literature related to this speciality is reproduced from original text of Nimitantra in Uttartantra of Sushruta samhita.
\end{abstract}

Correlation of Tritiya Patalagata kach with modern science is varies according to different authors, but according to some it can be correlated with different stages of senile immature cataract after considering the signs and symptoms and histological changes in the lens. One of the oldest concepts is that precipitation, denaturation, coagulation or agglutination of soluble lens protein is responsible for lens opacification. Accordingly after considering signs and symptoms, here correlating Kaphaja kach with Senile Immature Cataract. Senile immature Cataract is also called as age related Cataract. It is one of the major causes for the age related visual impairment and blindness. It affects 11.5 - to 15.5 million persons worldwide. At certain age of life, opacification of lens starts in everyone's eye which leads to gradual diminished vision or loss of vision. which means gradual opacification leads to cataract. According to modern science, senile immature cataract can be correlated with kaphaja kach. In modern science surgery is the only treatment available in cataract. In Ayurveda our Acharyas have mentioned various procedures like anjana, aschotana, pariseka, tarpana to delay kach or arrest the procedure of opacification. which can be useful in senile immature cataract.

Keywords: Kaphaja kach , Senile Immature Cataract, lens opacification, Tritiya Patalagata kach. 


\section{Introduction}

Kaphaj kach is a term used by Acharya Vagbhata in description. it is thoroughly taken as a previous stage of lingnash. lingnash is stage when there is a complete irreversible loss of vision Acharya vagbhata had also mentioned that if timir is neglected it causes kach and if kach is neglected it causes blindness. i.e lingnash.Thus timir and kach are the preliminary stages of lingnash which can be co-related with immature and mature cataract.

\section{Aims and Objects :}

To review the literature on Kaphaj kach and senile immature cataract to establish their relation.

\section{Material and Methods}

Symptoms of kach-

- Objects appear distorted,

- Dimension of vision increases,

- Objects can be appear red or black coloured, non existing things are seen due to visual hallucination(indriya-drushti vibhram).

- All these symptoms due to cataractous changes.

\section{Signs of kach-}

Red, bluish, white, black or mixed coloured drushti /drushti mandal is seen.

This indicates the papillary discoloration which is again due to cataractous lens according to Modern science. Change of colour of pupil from black in young age to grey in older age after 45-50years is due to increased density of nucleus. The different discolouration are as under-

1. Grey-immature cataract

2. white/pearly white-mature cataract

3. bluish white-hyper mature cataract

4. brown or black -hard cataract

5. Partial brown-morgagnian cataract

6. Blue, green or red coloured crystals in cortex-(parathyroid) Endocrine cataract

7. Calcified spots on anterior lens capsule-hyper mature cataract

8. Yellow/orange shade-highly myopic

9. Chalky white or white with yellow tinge-polychromatic lustre seen with slit lamp

10. Jet black pupil-aphakia/dislocated lens.

11. Vossius's Ring-Ring of brown granules just behind the pupil.traumatic cataract.

\section{In cataract-}

Cataract being degenerative disease, there are no inflammatory signs. The only sign is the papillary discoloration which depends upon the stages of the cataract.

- Immature-grey colour

- Mature-white colour

- Hyper mature-bluish white.

Brown or black discolouration may be seen due to deposition of melanin derived from amino acids from lens. This papillary discolouration can be seen with oblique 
illumination, whereas with Ophthalmoscope a black spot on reddish background of retina is seen in posterior sub capsular immature cataract.

Colour of lens is observed by slit lamp examination.

Other examinations are-

- Refraction under mydriasis,

- Visual acuity by Snellens chart,

- Direct Ophthalmoscopy and

- Auto refractometer.

\section{SAMPRAPTI OF KAPHAJ KACH}

प्राप्नोति काच्तां दोषे तृतीयपटलाश्रिते ।

तेनोऽर्ध्वमीक्षते नाधस्तनुचैलावृतोपमम् ॥

यथावर्णश्च रज्येत दृष्टि हीयेत च क्रमात । (अ.संः उ.तंत्र $२ ५ / ६-७)$

\section{Six stages of disease formation:}

- Stage 1, 2 - Vitiation of Dosha (Samchya,Prakop)

- Stage 3 - Ascend to the Jatrurdhwa (Prasara)

- Stage 4 - Netra- Rupa vaha siradrusti Madhya (sthanasamsraya)

- Stage 5 - 1st Patala (Avyakta), 2nd Patala (Vyakta),

- Stage 6- $3^{\text {rd }}$,patal (Bheda) immature cataract, $4^{\text {th }}$ patal mature cataract

\section{CLASSIFICATION OF KAPHAJ $\mathrm{KACH}$}

A. Based on the dominance of Dosha, 6 types of kach
1. Vataj kach
2. Pittaj kach
3. Kaphaj kach
4. Raktaj kach
5. Sansargaj kach
6. Sannipataj kach

\section{Prognostic}

classification:

\section{(Sadhyasadhyatva):}

In Ayurveda, a detailed description of the prognosis is available, as Sadhya, Kriccha Sadhya, Yapya \& Asadhya. The prognosis f a disease is usually depending upon its everity.

According to Acharya Sushruta, kach is yapya Vyadhi.
1. Vataj kach-yapya
2. Pittaj kach-yapya
3. Kaphaj kach-yapya
4. Raktaj kach-yapya
5. Sansargaj kach-yapya
6. Sannipataj kach-yapya

\section{Etiological classification:}

1. Nija

2. Agantuja

a. Sanimitta: Trauma to head 
b. Animmita: Darshana of Asura, Rishi, Gandharva

- Darshana of Sarpa,

- Darshana of Surya.

\section{Clinical features:}

The clinical features of kaphaj kach are dependent upon the site of lodging of pathological Doshas in Patalas.

\section{Features of Dosha Dushti}

According to Vagbhata:

Vataj kach :

- Lens colour - looks like covered in mud and smoke,

- Looks like clear, grey coloured.

Pittaj kach:

- Lens - looks bluish, glossy colour,

- falsely visualizes Light around sun and moon,

- Fire sparks and rainbow.

\section{Kaphaj kach;}

- Lens looks -white in colour

- Falsely visualizes scatterd dull coloured sun, moon everywhere.

\section{Sansargaj and Sannipataj kach}

- Various colours can be seen on lens.

\section{Raktaj kach:}

Kach will produces blood red colour or black discoloration in Drushti and the patient sees everything in the same colour.

\section{Senile immature cataract:}

Immature cataract is a clouding of the lens that leads to decreased vision, the light rays fall on lens of the eye which focuses an image onto the back of the retina ,this is where an image is processed and then sent to the brain. As cataract matures, it often causes glare, decreased vision contrast and colour sensitivity .At this stage of cataract, the lens begins to become opaque and optic disc view is hazy .The cortex remains clear. It is an incomplete(incipient) cataract.

\section{There are three main types of senile cataracts}

\section{Nuclear sclerotic}

As the lens grows, it constantly produces new fibres. The old fibres are pushed toward the centre of the lens, and When a person hits the mid age this process begins to cause the nucleus to harden. It typically blurs distant vision more than near vision. As time progresses the nucleus becomes diffusely cloudy. The cloudiness spreading gradually towards the cortex and occasionally it started to become brown.

There is however, considerable visual disturbance. At first a progressive myopia owing to the increased refractive index of nucleus, and then general impairment of vision; but progress is usually very slow.

\section{Cortical}

The cortex is the area that surrounds the nucleus when this area hardens and became opaque, difficult to see through, it is termed as cortical cataract. 
In this type, the most characteristic change is a demarcation of cortical fibbers owing to their separation by fluid.

This phenomenon can be only seen with a slit-lamp and is invisible ophthalmoscopicaly. The general increase in the refractive index of the cortex in old people gives a grey appearance to the pupil in contradistinction to the blackness seen in young ; the greyness initially due not to cataractous changes, but mainly to the increase in reflection and scattering of light.

Then gradually, spokes of opacity with clear areas between them appear in the periphery of the lens and lie in the cortex some in front and some behind the nucleus. Thus producing irregularities in refraction, some visual deterioratin and polyopia. The bases of wedge shaped opacities are peripheral an they are most common in lower nasa quadrant .At first they can only be seen with pupil dialated ,but as they develops their apices appear within the normal papillary margin. With oblique illumination pacities appear grey ;seen with ophthalmoscope, retinosope or slitlamp in retroillumination, they are black against red back ground of fundus;as they approach the axial area, vision becomes seriously disturbed.

As long as there is clear lens substance between the papillary margin of iris and the opacity, the iris throws a shadow upon grey opacity when light is cast upon the eye from one side. The proximity of the cortical opacity to the nucleus determines how the central vision is affected. Progression of cortical cataracts is usually very slow.

\section{Posterior sub capsular}

This type of cataract begins as a small opaque or cloudy area on the posterior or back surface of lens. It is called sub capsular because it forms beneath the lens capsule, which is a small sac or membrane that encloses the lens and holds it in place.

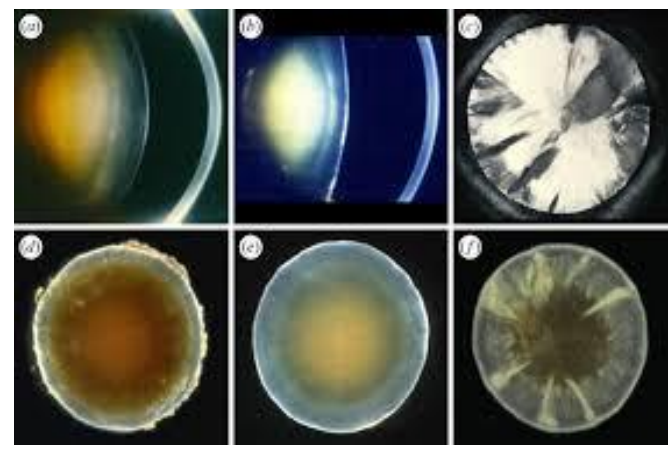

\section{Discussion:}

\section{Involvement of Patala in kaphaj kach:}

The involvement of patalas by various doshas is responsible for the development of cataract. Vihwala darshana (Blurring of vision) symptom is produced due to affliction of second Patala.

When third patal is affected Acharya Vagbhata has mentioned that in kaphaja kach person can see object which are upside but can't perceives those in downside and sees objects like they are diminished sun, moon and lamp and the drushti mandala of eye appears as white (Shweta varna) in colour. Initially, kaphadosha get vitiated. Its snigdha, sheeta, dravagunas are increased and are confined to rasa dhatu. Later sthira and guru gunas are increased. As a result, the transparent structure turns to dense white opacity.

Involvement of patalas in this progressive disease ultimately causing 
Linganasha i.e. complete loss of vision if not treated properly.

According to Sushruta, Timira, Kacha and Linganasha are the progressive stages of the disease Linganasha. But Vagbhatta consider Timira, Kacha and Linganasha as separate clinical entities. When the vitiated Doshas are situated in the first and second Patala the condition is termed as Timira. When the vitiated doshas affect the third patala, it is termed as Kacha; kaph pradhan kach is kaphaj kach, and when it involves the fourth patala, it is Linganasha.

\section{Conclusion:}

At the end of the study, following conclusions can be drawn on the basis of discussions in the present context.

\section{Kaphaj Kach can be compare} with Senile Immature Cataract on accour of its manifestations. Senile immature cataract generally occurs in an age group above 50, which is a physiological phenomenon. Blurred vision, glare, diplopia, floaters, are the common presentation in patients.

\section{References:}

1. Athavale A.D.; Ashtanga Sangraha; Godavari Publisher; Reprint 2004
2. Dutta L C; Modern ophthalmology; 3rd Edition; Jaypee Brothers Medical Publisher, Delhi; 2013

3. Garg Ashok; Ocular Therapeutics; 3rd Edition; Jaypee Highlights Medical Publishers; 2013

4. Kanski Jack J; Clinical ophthalmology; 7th Edition; Elsevier Saunders;2011

5. Khurana A.K; Comprehensive ophthalmology; 4th Edition; New age international; 2007

6. Mahajan B.K. ; Methods in Biostatistics; 6th Edition; Jaypee Brothers Medical Publisher, Delhi; 1999

7. Mishra Bramhashankar; Bhavprakash; 7th Edition; Choukhamba Sanskrut Sansthan, Varanasi; Reprint 2000

8. Nadkarni A.K ; Indian Medicinal Plants; Popular Book depot, Mumbai; 1956

9. Paranjape Prakash; Indian Medicinal Plants; 1st Edition; Choukhamba Pratishtahan,Delhi; 2002 Sihota Ramanjit, Tandon Radhika; Parson's Diseases of the eye; 21st Edition; Elsevier; 2011

10. The ayurvedic pharmacopoeia of india; 1st Edition; Controller of Publication civil lines , New Delhi; 2008

11. Tripathi Bramhanand; Ashtanga Hridayam; Choukhamba Sanskrut Sansthan, Varanasi; 2003

12. Tripathi Bramhanand; Charaka Samhita; Choukhamba Sanskrut Sansthan, Varanasi; Reprint 2004

Cite article

A comprehensive review of senile immature cataract and its correlation with kaphaj kach in ayurvedic literature.

Swapna R. Patil, Shilpa Dhote

Ayurlog: National Journal of Research in Ayurved Science- 2018; (6)(5): 1-6 